\title{
Ethnozoology in the mountains. What does the cognitive salience of wild animals tell us?
}

\author{
Matias Wajner ${ }^{1}$, Daniela Tamburini ${ }^{2}$, Fernando Zamudio ${ }^{3^{*}}$
}

\begin{abstract}
In recent times, ethnobiology has revived interest in cognitive aspects of humans' communities. A concept commonly used in this area is cognitive salience. In this paper we assess the wild animal salience meaning for the rural people from an area of the mountain range of the Córdoba province (Argentina). We also analyzed the relationship of cultural and ecological factors over wild animal domain salience. The values of cognitive salience, perception and cultural value were obtained by means of free lists to 16 collaborators, while semi-structured interviews were used to inquire about local ecological knowledge and ease of observation about wild animals. The interdependence between the five variables elaborated was analyzed through a Principal Components Regression. The results show a qualitative relationship between Cognitive Salience and Cultural Value and a significant correlation between Cognitive Salience and Local Ecological Knowledge. Ease of Observation did not correlate with Cognitive Salience, but show a significant relationship with the Perceived Abundance. The results suggest a complex network of factors that are modeling the cognitive salience and local perceptions over wild animals. In our findings, highlight the Cultural Value given to harmful animals which reflects an increasing pattern in the region, the conflict between rural people and wild animals. In turn a mutual influences and causal feedback loops between cognitive salience and an ecological factor, the Perceived abundance, is proposed. Investigations over cognition and about how people perceived nature can give us an idea of how they act in it, a compelling factor when it comes to cultural and biological conservation issues.
\end{abstract}

Keywords: Cognitive Approach; Ethnobiology; Animal Perceptions; Human-Wildlife Conflict

1 Independent Biologist, Las Golondrinas S/N (Unquillo-Córdoba)

2 Professor and researcher of Instituto de Investigaciones Biológicas y Tecnológicas IIBYT, (CONICET UNC), CERNAR FCEFyN UNC. Av. Vélez Sarsfield 1611, 5000 Córdoba, Argentina.

3 Grupo de Interacciones Ecológicas y Conservación, Instituto Multidisciplinario de Biología Vegetal, Universidad Nacional de Córdoba-CONICET, Av. Vélez Sarsfield 1611, 5000 Córdoba, Argentina.

* Corresponding author. $\mathrm{E}$ E-mail address: FZ (zamufer@yahoo.com.ar)

\section{INTRODUCTION}

Trends towards practice-oriented perspective has been pointed out as the most recent stage of ethnobiology in the current context (Ludwig 2018a). This perspective, however, has not prevented the discussion of novel themes and approaches even from other areas of thought such as anthropology (Medrano 2014; Ludwig 2016; 
Rival 2016). So too, some authors have been re-digging over other topics apparently forgotten for the ethnobiology as those related to cognitive approaches (Gosler 2017; Ludwig 2018a; 2018b). Those works that propose the integration of cognitive, biological and sociocultural factors have been valued. In this way, the ethnobiology renewed interest over cognitive issues is currently evoking new praise (Descola 2016: 158-159; Rival 2018). On one hand, Ludwig (2018a: 271) notes that "A systemic perspective on causal interactions between biological, cognitive, and sociocultural factors provides opportunities for more integrative research but also comes with challenges for researchers with different disciplinary perspectives". On the other hand, Rival (comments to Ludwig 2018b) highlights the "pragmatics of reasoning in the fire of social action" of this perspective. In this paper we assess the animal salience meaning and analyzed the factors that model the answer over wild animal domain, as form to generate a more comprehensive view on ways of thinking and acting in nature of local people.

There are different types of salience (e.g. phenotypic, perceptual, cultural, and ecological) and different ways of measuring it (See Gosler 2017). All types of salience together make a global salience (Hunn 1999). Here, we understand that overall salience is equivalent to cognitive salience and throughout the paper will be used as interchangeable concepts. In this framework, overall salience can be defined as the place occupied by different elements of nature in human cognition and is generally obtained through the analysis of free listings (Weller and Romney 1988; Berlin and Kay 1991; Sutrop 2001; Quinlan 2005; Bernard 2006). It is proposed that the position in which the species appear in these lists is related to the cognitive salience of these elements (Berlin and Kay 1991). These lists can give a notion of how well the main constituents of a domain are agreed by a group of people who share a common language and culture (Balée and Nolan 2015). At the same time, it allow to elucidate the emic semantic content and its meaning through linguistic analysis.

As explained above, cognitive salience is a concept closely related to the technique of free listings and among its assumptions we find possible interpretations of its meaning. Balée and Nolan (2015) point out that the objects in the free listings are: a) mentioned in order of familiarity, b) the first elements listed tend to be prototypical (i.e., elements that best explain a domain sensu Rosch 1976) and/or the more salience "locally", and c) that knowledgeable people in a domain mention more elements than those who are not experts, so it is an indirect way of measuring knowledge (See too Quinlan 2005; Quinlan and Quinlan 2007).

The cognitive salience that a group of people has on the elements of their environment, including animals, depends both on the cultural value that is given to them, as well as on a series of morphological, ecological and behavioral aspects related to their appearance (Hunn 1999; Atran et al. 2002; Gosler 2017; Zamudio and Hilgert 2018). These last aspects are related to the human ability to observe the animals in their environment (Bentley and Rodriguez 2001). On one hand, the cultural value of an animal or plant has been generally calculated on the basis of the material-utilitarian value (Pieroni 2001, Reyes García et al. 2006). Although symbolic and non-material utilitarian values have been considered in their meaning (Bentley and Rodríguez 2001, Monroy and Flores 2015), in practice they have not been quantified in any estimator or index. In that 
sense, the ease of observation, can be understood as the set of ecological attributes (e.g., abundance), behavioral (e.g., vocalizations, home-range) and morphological (e.g., size, color) of the species that make them more visible for the human senses (Bentley and Rodriguez 2001). According to Gosler (2017:638), "salience therefore involves all aspects of both what captures the observer's attention and why". For that, also emotion plays a critical role in ethnobiological information processing (Nolan et al. 2001). For example, the most "liked" animal domains and the most "disliked" animal domains should be among the most salience in an individual's semantic space (Nolan et al. 2006). But, the most salience animals can go unnoticed in other cultural context where the same animal is present. The question is, then, why do some animals stand out more in human cognition than others? In short, are the most salience animals the most culturally important and/or the easiest to observe?

To date, few studies have analyzed the relationship between cognitive salience, cultural importance and ease of observation of wildlife animals (see Gosler 2017). For example, Bentley and Rodriguez (2001) propose that there is a relationship between ease of observation, cultural importance and local knowledge, although they do not analyze the relationship between these factors and cognitive salience. Zamudio and Hilgert (2018) also analyzed the cognitive salience of rural inhabitants over stingless bees (Apidae: Meliponini) domain. They found that Yateí (Tetragonisca fiebrigi) was the most salience species, the best known, and also the one that had the highest cultural value given the profuse medicinal use of its honey, but contrary to expectations, the use of stingless bees was not associated with its appearance (ease of observation or Zamudio et al. 2010; Kujawska et al. 2012).

In the present investigation we proposed that the cognitive salience that the inhabitants possess about wild animals is related to cultural factors and the perception that the inhabitants have of the fauna. In this way, we hope to find that the cognitive salience on the animals is related: a) positively with the cultural importance, b) positively to ease of observation; c) positively with local ecological knowledge.

\section{MATERIAL AND METHODS}

\section{Study area and people}

The work was carried out on the upper floor (1800-1900msnm) of the Sierras Grandes mountain range in the province of Córdoba, Argentina (Figure 1), near the "Cuchilla Nevada" point at $-31.381103^{\circ}$ latitude $-64.750783^{\circ}$ length. The ecosystem is considered a biogeographic island where speciation processes have been favored (Cabido 1998; Punta et al., 2014). This is a natural water catchment area, which is why rivers are with transparent and cold waters abound (Ferriz et al., 2010).

Throughout most of the year, environmental conditions are hostile to local people due to low temperatures, frequent drizzle, haze and strong winds (Cabido 1985; Renison et al. 2002). The human population, peasant livestock families, is distributed dispersed family houses, generating a marked isolation among the family nuclei, with a low populational density. It has been pointed out that isolation deepens the link between these people and the environment that surrounds them, shaped their particular way of being (Cáceres 2004; Punta et al. 2014). The main productive activity are cattle and sheep 


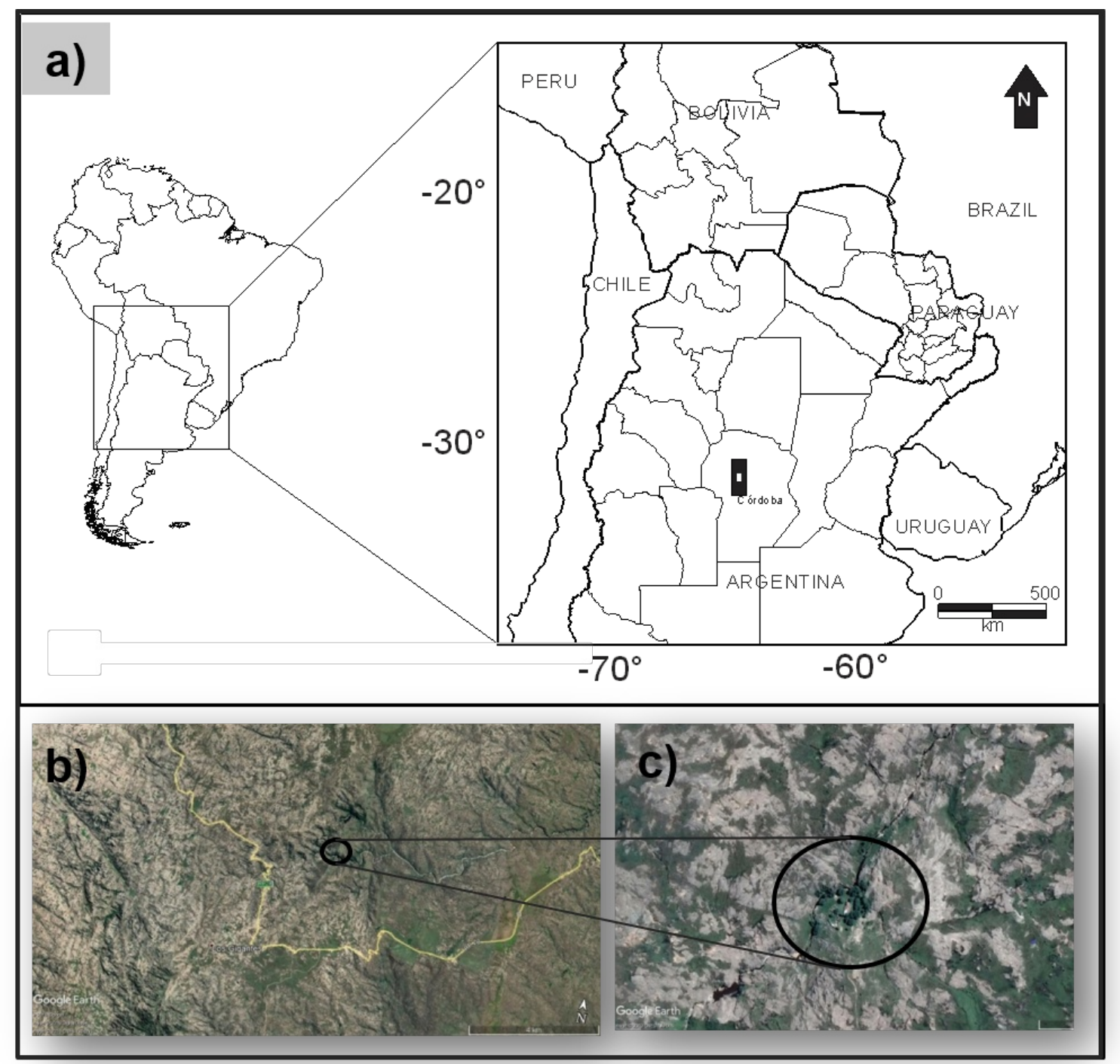

Figure 1. Study site. a) general reference in South America and Argentina. A black rectangle shows the area occupied by Sierras Grandes in Córdoba province and in white is show the study area in the "Cuchilla Nevada"; b) satellite image over a part of study area. In yellow is show Provincial Route 28 (take of Google Earth); c) zoom over a typical family house in the area.

breeding (Cáceres 2001, 2004; Ryan 2004; Cingolani et al. 2008), to which are added activities such as artisan production and the sale of labor force for construction, the care of stays and other temporary jobs (changas) that are realized outside the farm.

\section{Methods}

The choice of collaborators for this study was made through the snowball method
(Martín Crespo and Salamanca 2007) based on pre-established contacts with non-local residents who regularly visit the area in the last 15 years. The non-local residents (some relatives of $\mathrm{MW}$ ) were as a shortcut to the collaborators in the area. The relationships of trust with some of the residents allowed us to enter the study area more directly, and begin to inquire about other possible participants for our research. The interviews were conducted with the family group 
without distinguishing whether the answer was given by the man or the woman, since it was not an objective to include a comparative factor between the two. Proportionally more interviews were conducted with men than with women. The inhabitants of the area of "Cuchillas" are elderly people (average of 58.7 years), since young people leave the area to towns and cities with more employment opportunities.

The field work followed the general course of an ethnobiological work given in stages. A first stage of interpersonal knowledge and presentation of ideas, in which informed consent was obtained. A second stage where we applying free interviews, free listings and finally where realized semi-structured interviews (Bernard 2006). We visit at least three times to each collaborator and in some cases we have visited up to seven times. We followed the Latin American Society of Ethnobiology Code of Ethics guidelines were followed (SOLAE Ethics Committee et al. 2018).

Before analyzing the free lists, domestic animals and the general categories such as "birds" or "snakes" were no contemplated to calculate cognitive salience. In turn we identify the names that are synonymous and unify some ethnospecies, which according to the criteria of the authors and of some of the consulted collaborators, corresponded to the same animal. The correspondence between the ethnospecies (i.e. according to the local categories) and the biological species was carried out in conjunction with the collaborators with the help of photos and wildlife guides, and through crossing of information about the existing fauna in the area (Canevari and Vaccaro 2007; Narosky and Yzurieta 2010). For the generic local categories such as "mice" or "ducks" the scientific names of all related species present in the area were included. Finally, all ethnospecies that were mentioned less than three times, were not contemplated for the analysis because they were considered of low consensus. That is a criterion more rigorous than the proposal commonly used, in which the elimination of unique appointments is suggested (Benz et al. 1994).

The complete methodological procedure can be seen schematically in Figure 2. The free listings were made under the question "please, name the animals you know in the area" (Sutrop 2001; Quinlan 2005; Bernard 2006; Quinlan and Quinlan 2007). After obtaining a first list, we asked again, "Any other that comes to mind?". This did not mean a structured and fixed task, but rather it was developed within the framework of a dialogue in which other issues and referents related to the animals in question could be derived. With the set of individual lists, overall cognitive salience was calculated (Figure 2, a). This produced a unique list of ethnospecies that were ordered from highest to lowest cognitive salience. This varies between 0 (the least salience items) and 1 (the most salience items). The formula used being the following (Sutrop 2001): CS = F I $(\mathrm{N} \mathrm{mP})$. Where $\mathrm{CS}=$ Salience; $\mathrm{F}=$ Frequency of appearance of the item in the listings; $\mathrm{mP}=$ Average position of the item in all the lists; and $\mathrm{N}=$ total collaborators.

Then the list was divided into three equal parts and five ethnospecies of each third were selected (high, intermediate and low salience) count a total of 15 ethnospecies (Figure 2, b). With these ethnospecies we work to evaluate the relationship between Cognitive salience, Ease of observation and Local ecological knowledge (Figure 2, e and f) while the rest of ethnospecies were not considered for quantitative salience analyzes. We select 15 ethnospecies taking into account the time takes to conduct Ease 


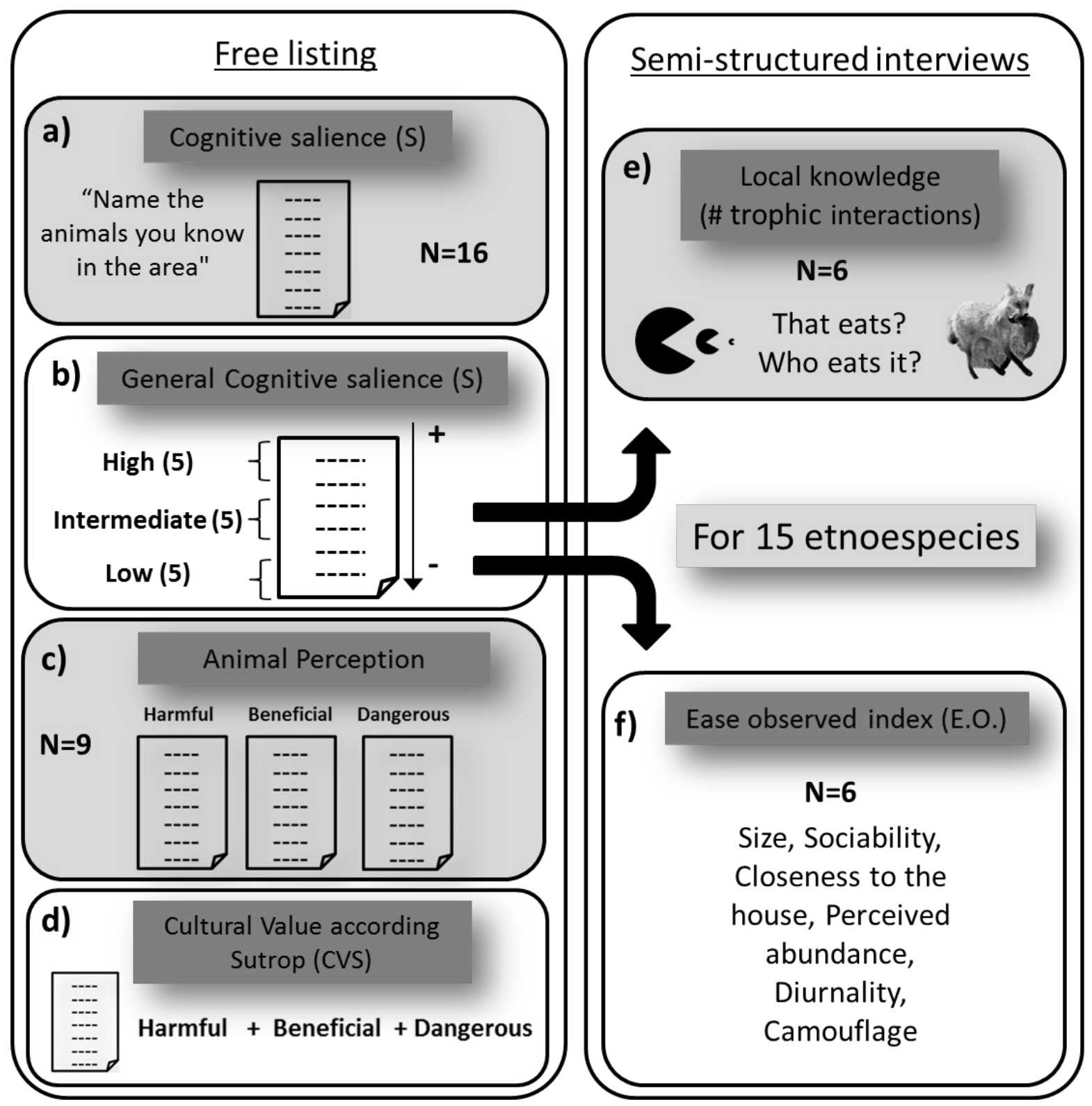

Figure 2. Methodological scheme used in the study: a) individual free lists to 16 collaborators to know the cognitive salience on wild animals; b) Selection of species of high, medium and low cognitive salience; c) Animal perception; three free listings per person to a sub-sample of nine collaborators; d) Unification of perception lists and obtaining CVS; e) Semi-structured interviews over Local Ecological Knowledge (number of trophic interactions) in a sub-sample of six collaborators; $f$ ) calculation of ease of observation index based on 6 mixed-sources criteria; emic (local residents) and etic (consult specialist and bibliography).

of observation and Local ecological knowledge interviews. We prioritize a balance between the respondents' capacity for attention and the quality of the information obtained. In addition, the most representative species used of each third of salience (the first 5 of each group) allowed us to weigh the subtle differences between each animal when selecting groups of animals with contrasting salience values.

To know the perceptions about the wild fauna, three free lists about the beneficial, 
harmful and dangerous animals were made to a total of nine collaborators (e.g., are the beneficial animals that are in the area?). Also, we asked about the reason of the inclusion of each ethnospecies in the respective lists. The animals of low consensus, with a single mention, were not considered for the analysis in this subsample (Benz et al. 1994). With the free lists obtained two analyzes were carried out. First, values of perception of each category were obtained using the Sutrop formula (Sutrop 2001). Secondly, the three free lists mentioned above were unified in a single list to generated an index called Cultural Value according to Sutrop (CVS). The analysis proposal used arises from considering the expanded concept of cultural importance of Bentley and Rodriguez (2001) in which both the material utilitarian value and the nonmaterial utilitarian value of the fauna are considered.

To calculate the individual local ecological knowledge (LEK) and some variables of the observation facility index, we worked with a sub-sample of six key collaborators (Figure 2 , e and f). We worked only with six key collaborators for two reasons; first they showed greater predisposition to share their knowledge, and in general they mentioned more ethnospecies in the free listing. Second, the tasks to be done in this stage (measure LEK through the number of interactions and the information to perform the OF index) demand more time, require more attention and also own interest for our study as given by these key collaborators.

Through semi-structured and open interviews (Martin 1995, Guber 2012), LEK was inquired through trophic questions, ie, what eats and who eats each of the 15 selected animals. From this, all the interactions that were recognized to each of the animals were counted and a value of
LEK was obtained for them, represented by the variable "number of trophic interactions" (NTI). On the other hand, the Ease of Observation Index of the ethnospecies (EO) was calculated for each of the 15 species previously selected (Figure 2, f) using the categories proposed by Bentley and Rodriguez (2001) to classify animals according ease of observation. It was decided to dispense with the "noisy" category and the variable "proximity to the home" was added. The Table 1 shown the Ease of Observation Index components, the categories used, the valued assigned, a description of the logic used to assign values to each category and the forms of obtaining the information about each term. The formula proposed in this paper is the following: $\mathrm{EO}=(\mathrm{Si} / 3+\mathrm{S} / 2+\mathrm{CH} / 3+\mathrm{PA} /$ $4+\mathrm{AAC} / 2+\mathrm{C} / 3) / 6$. Each terms which forms the index of ease of observation was divided by the number of categories assigned to each one and the sum of the components was divided over the total number of terms. Thus, the observation facility index can obtain values between 0 (minimum EO) and 1 (maximum EO). The variables Sociability, and Camouflage were obtained from consultation with a specialist wildlife researcher (Phd. Ricardo Torres) and bibliographical information (Torres and Tamburini 2018).

\section{Data analysis}

We performed a Principal component regression (PCR) for analyzing the interdependence between variables: Cognitive salience (S), Number of trophic interactions (NTI), Ease of observation (EO), Size and Perceived abundance (PA). In $P C R$, instead of regressing the dependent variable on the explanatory variables directly, the principal components of the 
Table 1. Ease of Observation Index components.

\begin{tabular}{|c|c|c|c|}
\hline $\begin{array}{c}\text { Terms of EO } \\
\text { index }\end{array}$ & $\begin{array}{c}\text { Categories and } \\
\text { values }\end{array}$ & Descriptions & $\begin{array}{l}\text { Ways of } \\
\text { obtaining }\end{array}$ \\
\hline Size (Si) & $\begin{array}{c}\text { Small (1), } \\
\text { medium (2), large } \\
(3)\end{array}$ & $\begin{array}{c}\text { Bigger } \\
\text { (conspicuousness) } \\
\text { animals are more } \\
\text { ease of observe than } \\
\text { little animals. }\end{array}$ & $\begin{array}{l}\text { Interviews with } \\
\text { local } \\
\text { collaborators } \\
(\mathrm{N}=6)\end{array}$ \\
\hline Sociability (S) & $\begin{array}{l}\text { Lonely (1); } \\
\text { Gregarious (2) }\end{array}$ & $\begin{array}{c}\text { More sociable } \\
\text { animals are more } \\
\text { ease of observe than } \\
\text { solitary animals. }\end{array}$ & $\begin{array}{l}\text { Consultation with } \\
\text { a specialist and } \\
\text { bibliographical } \\
\text { information }\end{array}$ \\
\hline $\begin{array}{l}\text { Closeness } \\
\text { housing }(\mathrm{CH})\end{array}$ & $\begin{array}{l}\text { It stays very far } \\
\text { from the house } \\
\text { (1); Does not } \\
\text { approach to the } \\
\text { vicinity of the } \\
\text { house (2); It } \\
\text { approaches the } \\
\text { vicinity of the } \\
\text { house (3) }\end{array}$ & $\begin{array}{c}\text { Animals which } \\
\text { approaches to the } \\
\text { houses are easier to } \\
\text { observe than animals } \\
\text { that not approach } \\
\text { houses or avoid } \\
\text { humans. }\end{array}$ & $\begin{array}{l}\text { Interviews with } \\
\text { local } \\
\text { collaborators } \\
(\mathrm{N}=6)\end{array}$ \\
\hline $\begin{array}{l}\text { Perceived } \\
\text { abundance } \\
\text { (PA) }\end{array}$ & $\begin{array}{l}\text { Rare (1), Little } \\
\text { abundant (2); } \\
\text { Abundant (3); } \\
\text { Very abundant } \\
\text { (4) }\end{array}$ & $\begin{array}{l}\text { Abundant animals } \\
\text { are more ease of } \\
\text { observe than scarce } \\
\text { or rare animals. }\end{array}$ & $\begin{array}{l}\text { Interviews with } \\
\text { local } \\
\text { collaborators } \\
(\mathrm{N}=6)\end{array}$ \\
\hline $\begin{array}{l}\text { Activity } \\
\text { according to } \\
\text { circadian } \\
\text { rhythm (AAC) }\end{array}$ & $\begin{array}{l}\text { Nocturnal (1); } \\
\text { Diurnal (2) }\end{array}$ & $\begin{array}{c}\text { Diurnal animals are } \\
\text { more ease of } \\
\text { observe than } \\
\text { nocturnal animals }\end{array}$ & $\begin{array}{l}\text { Interviews with } \\
\text { local } \\
\text { collaborators } \\
(\mathrm{N}=6)\end{array}$ \\
\hline $\begin{array}{c}\text { Camouflage } \\
\text { (C) }\end{array}$ & $\begin{array}{l}\text { Camouflaged (1); } \\
\text { not camouflaged } \\
\text { and/or has } \\
\text { striking colors (2) }\end{array}$ & $\begin{array}{l}\text { Camouflaged } \\
\text { animals are more } \\
\text { ease of observe than } \\
\text { animal of bright } \\
\text { colors. }\end{array}$ & $\begin{array}{l}\text { Consultation with } \\
\text { a specialist and } \\
\text { bibliographical } \\
\text { information }\end{array}$ \\
\hline
\end{tabular}

explanatory variables are used as regressors. To perform the PCR we used the Infostat program (Di Rienzo et al. 2008). In addition, a qualitative analysis was made over the relationship established between the cognitive salience given to different animals and the cultural value of them.

\section{RESULTS}

As a whole the collaborators mention a total of 45 ethnospecies of wild animals. The ethnospecies mentioned belong to 6 taxonomic classes, with birds (54\%) being the best represented class, followed by mammals $(31 \%)$, reptiles $(9 \%)$, and finally amphibians, fish and arachnids (2\%). The representativeness of the taxonomic classes' changes markedly among the three groups of ethnospecies selected according to the degree of cognitive salience. The relative proportion of mammals is highest within the entnospecies of high cognitive salience $(67 \%)$, and is minimal for the group of animals of low cognitive salience $(6 \%)$. In addition, it is observed that birds are poorly represented in the group of high cognitive salience $(33 \%)$ unlike the groups of intermediate $(67 \%)$ and low salience $(60 \%)$ where they are best represented.

The animals of high salience are the Zorro (Fox, Lycalopex culpaeus smithersi), Puma (Puma concolor), Vizcacha (Plains viscacha, Lagostomus maximus), Liebre (Hare, Lepus europaeus) and Condor (Vultur 
gryphus). Those of intermediate salience are the Patos (Duck, Anas flavirostris or $A$. georgicas), Cuis (Southern Mountain Cavys, Microcavia maenas or Galea leucoblephara), Trucha (Trout, Oncorhynchus mykiss), Comeperro (Turkey vulture, Cathartes aura) and Chingolo (Rufous-collared sparrow, Zonotrichia capensis). While in those of low salience are the Lechucita de las
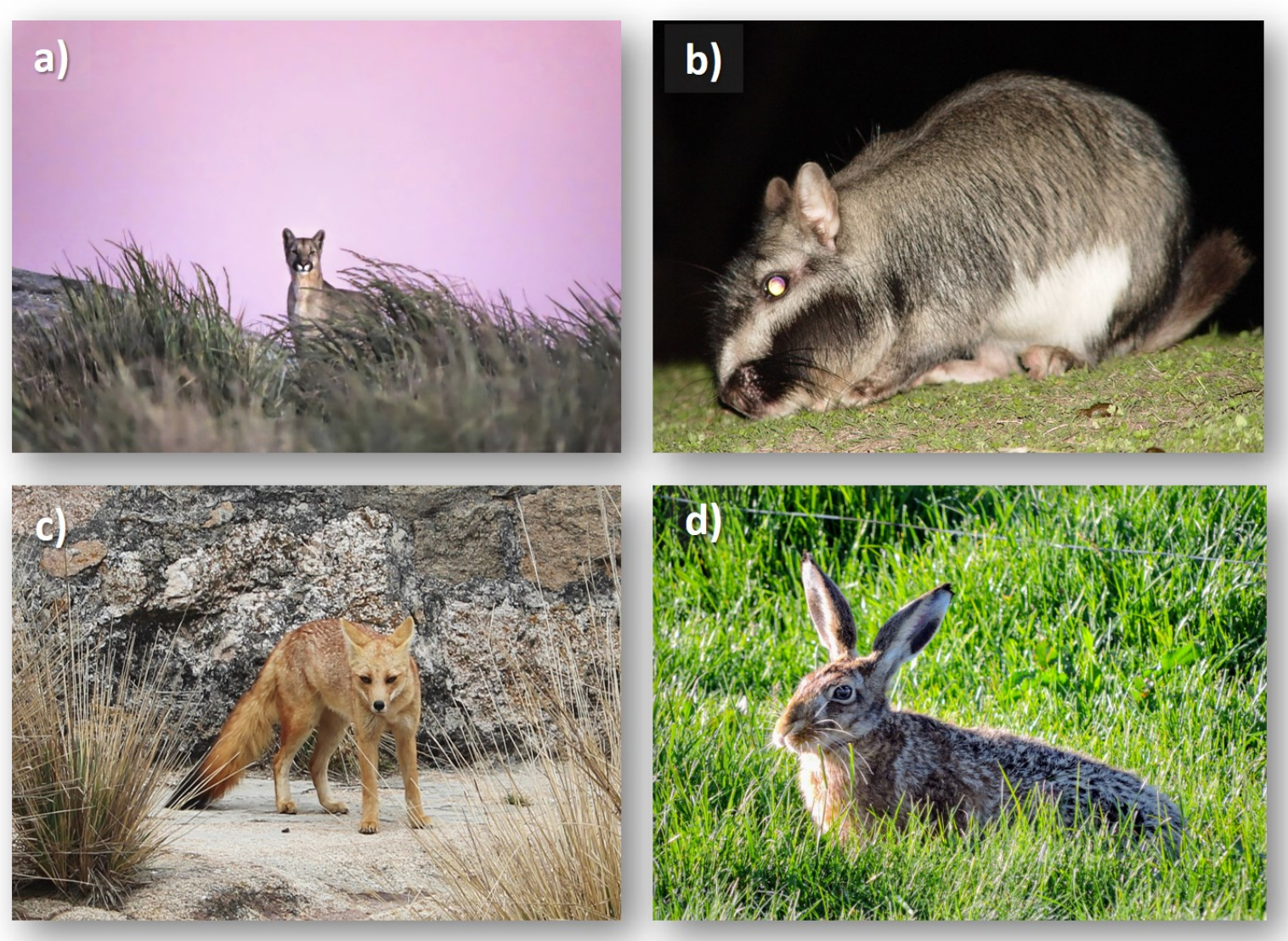

vizcacheras (Burrowing Owl Athene cunicularia), Víbora del agua (Water viper, Lygophis vanzolinii or L. anomalus), Calandria (Chalk-browed Mocking bird, Mimus saturninus), Chimango (Chimango Caracara, Milvago chimango) and Víbora ratonera (Viper mousetrap, Phylodrias patagoniensis) (Figure 3).

Figure 3. Ethnospecies of greater cognitive salience in the zone of "Cuchillas" of Sierras Grandes de Córdoba; a) Puma (picture: Gabriel Orso), b) Vizcacha (Picture: Daniela Tamburini), c) Zorro (picture: Esteban Kowaljow) and d) Liebre (picture: Gabriel Orso).

\section{Local perception about fauna}

In general, from the first interviews the references to the conflicts between the inhabitants of the area and some harmful species were notorious. This is reflected in the discurses and also in results of the free

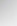

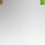


(0.37) have the higher values. The animals that cause damage were easily identified, in fact, with the exception of the Jabali (Wild boar, Sus scrofa) all belong to the group of animals considered of High Cognitive salience in this study. The villagers refers to these as "dañinos" (harmful), "perniciosos" (pernicious), "malditos" (cursed), "maliciosos" ( malicious), "plaga" (plague) or "desgraciados" (unfortunate) and other apelatives of negative connotations. Zorro and Puma are animals that attack domestic livestock (cattle or sheep) and cause important economic losses according to the collaborators. Some oral narratives indicate that the Puma in one night, teaching hunt their breeding's, can kill between 10 and 15 lambs, without even eating them. Another of the harmful species is the Carancho (Southern Caracara, Caracara plancus), which stands out as a hunter with the ability to kill even lambs breedings. Were also mentioned as harmful those opportunistic ethnospecies that can prey on poultry, eggs or even so young lambs such as the Zorrino (Skunk, Conepatus chinga), Comadreja (White-eared oposum, Didelphis albiventris), Huron (Lesser grison, Galictis cuja) and Aguila (Black-chested Buzzard-Eagle, Geranoestus melanoleucus). Other ethnospecies are considered harmful for destroying the soils of fields, pastures and crops such as Vizcacha, Pecarí (Collared peccary, Pecari tajacu) and Jabalí. At the same time, the Jabalí is considered harmful because it pregnant the domestic pigs, decreasing the sale value of the "crossed" offspring. It should be noted that the Condor was indicated as predator of young cattle.

The most dangerous animals are the Puma and Jabalí (0.4). When asked about dangerous animals, most of the collaborators pointed out that "there are not many" in the area. The danger is a circumstantial possibility; "Todo animal te va a morder pero si vos lo querés agarrar, si no no...." ("Every animal is going to bite you but if you want to grab it, if not, not", Oral narrative $\mathrm{N}^{\circ} 14$, R.A. 31/08/2017). In this way we can identify two types of dangerous animals, on the one hand large animal with some outstanding dangerous character such as the tusks and aggressiveness of the Jabalí or Peccary. On the other hand, those animals that have some type of poison as scorpions and snakes.

Finally, between the highest beneficial animals are the Vizcacha (0.75) and Liebre (0.36). In this category appear mainly wild animals that can be eaten, however, hunting for food is an activity that only some residents of the area practice. The Puma is a particular case, since it is hunted only when it causes damage, but once killed, the meat is appreciated and the fat used for medicinal purposes. Animals or part of animal for handicrafts were not mentioned although during the interviews we collected narrations about the importance of the leathers and skins of some animals in the past when they presented high market values (e.g. Vizcacha, Zorrino, Zorro leathers, etc.).

\section{Wildlife's cultural value}

Among the ethnospecies with high cultural value, the great majority $(61 \%)$ belongs to the group with the greatest cognitive prominence, followed by those of intermediate level (28\%) and those of low importance (11\%), that occupy a marginal place in this list (Figure 4). As can be seen, the first and second animals with the largest CVS have contrasting values in the perception lists. That is, both have a great cultural value, but the Puma for being a harmful and dangerous species, and the Vizcacha for being a beneficial species. The 


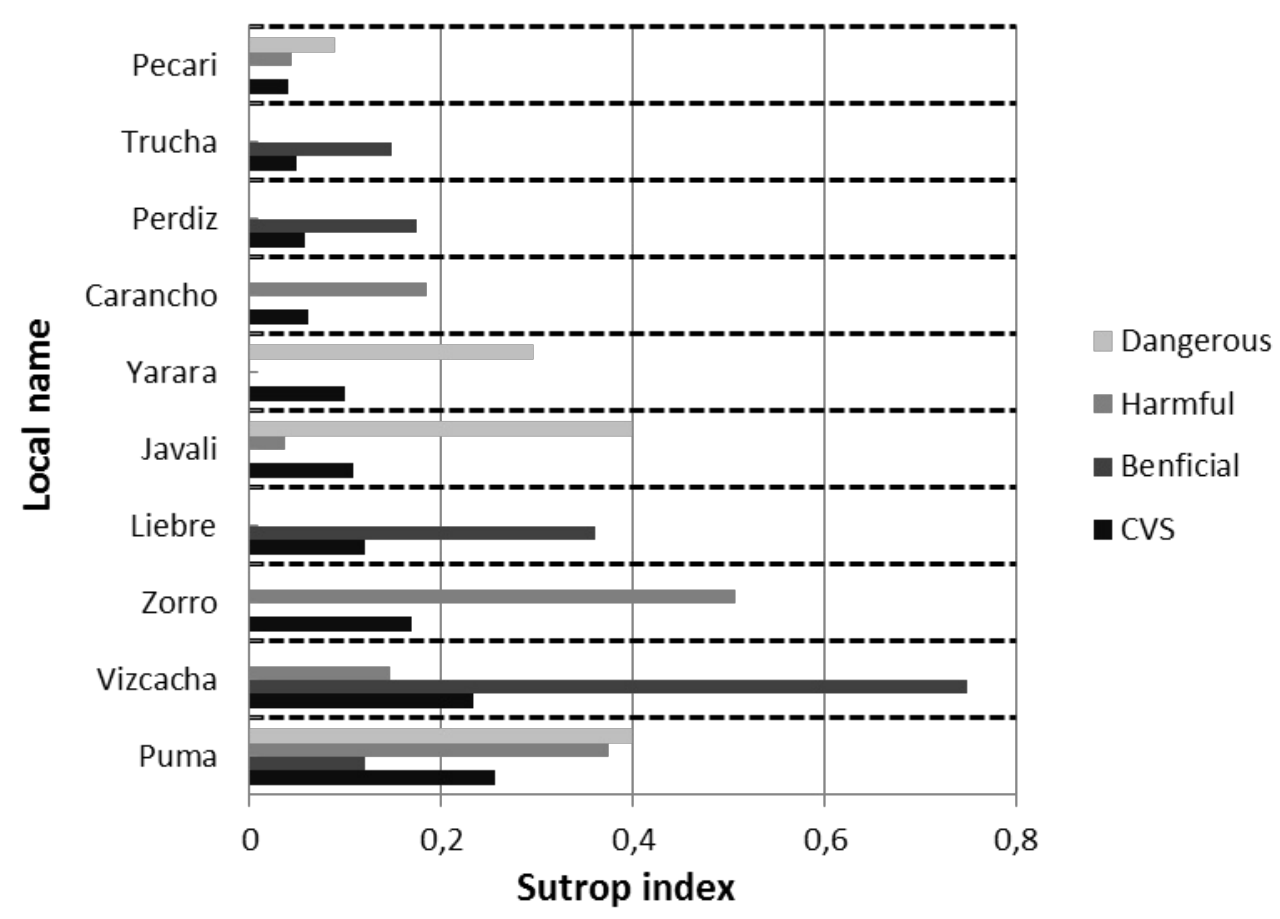

Figure 4. Perception (dangerous, harmful and beneficial animals) and Cultural Value according Sutrop (CVS) of the 10 most salient ethnospecies.

same happens with the Zorro and the Liebre, respectively, the third and fourth largest CVS animals.

\section{Ethnospecies Local ecological knowledge and ease of observation}

According to the number of total interactions mentioned (NTI) the most known ethnospecies in the area are Zorro (68), Vizcacha (45) and Puma (44). The lowest values observed correspond to Comeperro (6), Chimango (11) and Cóndor (12), three birds of habit mainly scavengers. The local collaborators indicate that these birds feed on "dead things" without mentioning the species consumed (ie. potentially all dead animal species), which affects the number of interactions of these species. This also contrasts with the knowledge on habitat, nesting sites and behavior that the inhabitants present and that were reflected in the stories about these birds.

The values of the Ease Observation (EO) for each ethnospecies oscillated between 0.843 and 0.535 . The highest values being those of the Condor (0.843), Pato (0.791) and Vizcacha (0.787). The lowest values were registered for Calandria $(0,641)$, Chimango $(0,620)$ and Víbora ratonera $(0,565)$.

\section{Relating cognitive salience}

The Figure 5 shows the results of PCR. The first three latent variables explain $95 \%$ of the variation of the relationship between the variables analysed (Figure 5). The first latent variable (CP 1) explains $61 \%$ of the variation and shows a positive association principally with the Cognitive Salience (CS), Perceived Abundance (PA) and Ease of Observation (EO) (Table 2). The second latent variable (CP 2 ) comprises $20 \%$ of the 
variation and is associated positively with Size and negatively with the Number of trophic Interactions (NTI) reported by local people, a variable that explains Local
Ecological Knowledge (Table 2).

The variable Size correlated positively with CP1, but the relationship between this variable and CP2 was stronger. The third

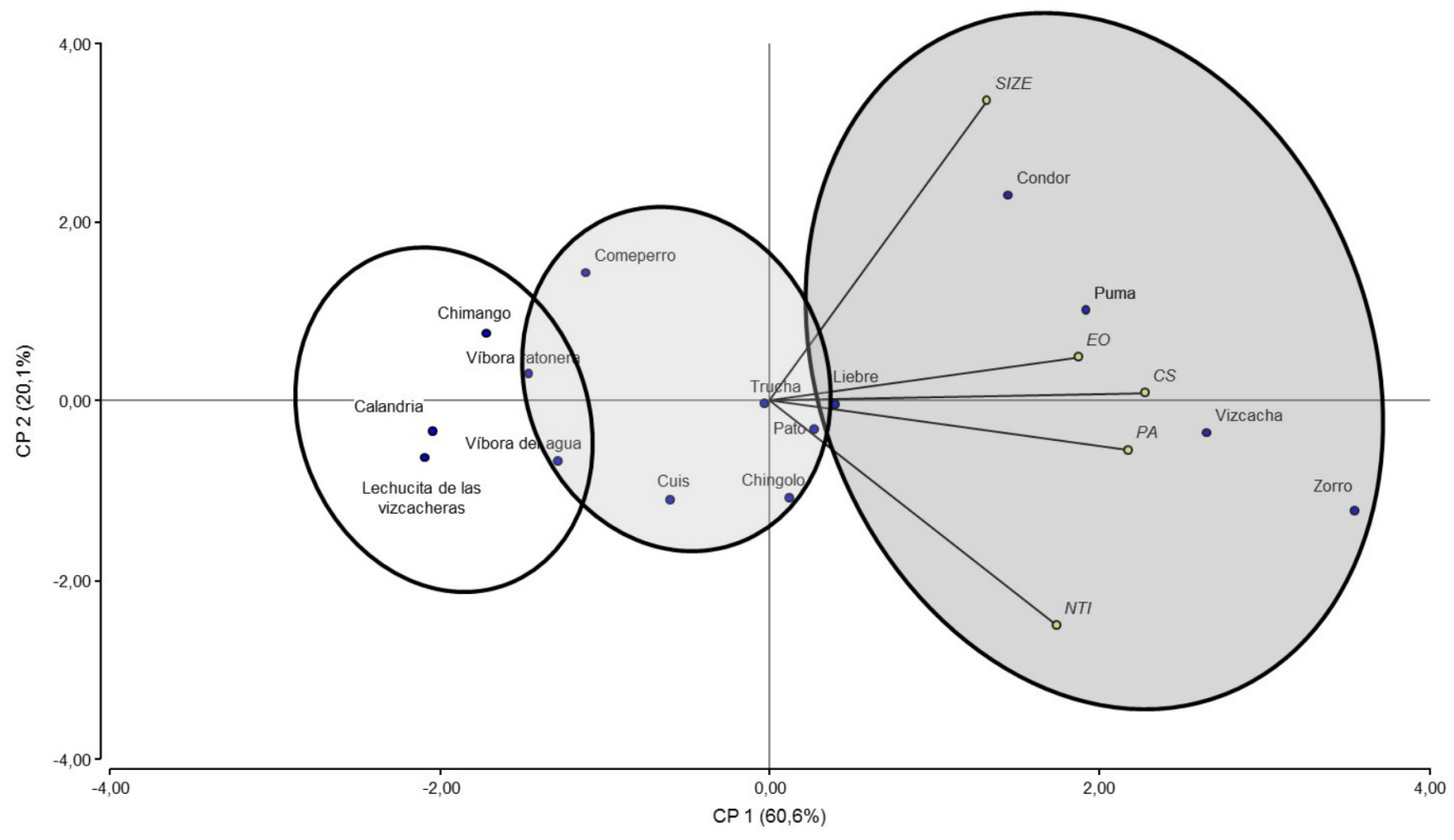

Figure 5. Graphical representation of the PCR. In circles the ethnospecies of high salience (dark gray), intermediate salience (light gray) and low (bottomless) salience are indicated.

latent variable (CP3) explained $15 \%$ of the variation and only is correlated to the EO but with a low coefficient. That result and the no significant negative relationship with three of five variables analysed, indicate that CP3 explain others dimension of the EO no explained by the Cognitive Salience variable. In turn, we observed a significant correlation between Salience and NTI and in smaller measure between Salience and Perceived abundance and Size. At the same time NTI correlate with Perceived abundance although moderately. The high correlation between EO and NIT is redundant, as the EO index contains the PA variable.

\section{DISCUSSION}

We began this work asking why some animals are more salience than others in human cognition. For this we the link between cognitive salience and biological and sociocultural variables, that we hypothesized could explain this slippery concept of multiple academic origins and various uses (e.g. from linguistics to neurosciences).

In order to contextualize our findings, we first think it appropriate to clarify the relationship between cognitive salience obtained through free listings, and other concepts related to this technique such as familiarity and prototipicality (Baleé and Nolan 2015). I.e., the relation between the 
Table 2. Correlation matrix and Linear Regression (PCR) between selected variable: Cognitive Salience (CS); Number of trophic Interactions (NTI); Ease of observation (EO); Size; and Perceived Abundance (PA).

\begin{tabular}{c|c|c|c|c|c|c}
\hline \multirow{4}{*}{$\begin{array}{c}\text { Correlation matrix } \\
\text { (coefficients) }\end{array}$} & & CS & NTI & EO & Size & PA \\
\cline { 2 - 7 } & NTI & $0,75^{* *}$ & 1 & 0,31 & 0,02 & $0,56^{*}$ \\
\cline { 2 - 7 } & EO & 0,51 & - & 1 & 0,34 & $0,75^{* *}$ \\
\cline { 2 - 7 } & Size & $0,60^{*}$ & - & - & 1 & 0,28 \\
\cline { 2 - 7 } & PA & $0,73^{*}$ & - & - & - & 1 \\
\cline { 2 - 7 } & $\mathrm{CP} 1(61 \%)$ & $0,87^{* * *}$ & $0,50^{*}$ & $0,58^{* *}$ & $0,29^{*}$ & $0,79^{* *}$ \\
\cline { 2 - 7 } & $\mathrm{CP} 2(20 \%)$ & 0,0005 & $0,35^{* *}$ & 0,01 & $0,63^{* *}$ & $0,02^{\mp}$ \\
\cline { 2 - 7 } & $\mathrm{CP} 3(15 \%)$ & $0,11^{*}$ & $0,12^{*}$ & $0,34^{*}$ & $0,08^{¥}$ & 0,09 \\
\hline
\end{tabular}

${ }^{* \star *} P<0,0001 ;{ }^{* *} P<0,001 ;{ }^{*} P<0,05$. ¥Negative relationship.

salience and the forms of classification of the discontinuities of nature, mental operations that can overlap when asking about the order of elements in a list. Familiarity and prototypicality are closely related concepts, while Rosch (1976) has proposed familiarity (or family resemblance hypothesis) as a distinctive element in the formulation of categories. That hypothesis argues that a series of items are grouped around a prototypical specimen that best explain a domain according to familiar similarity between constituents (Rosch and Mervis 1975). In turn, the most prototypical constituents tend to be the most salience cognitively (Zamudio and Hilgert 2015; Zamudio and Hilgert 2018). Hence, it is likely that familiarity, prototypicality, and Cognitive Salience (CS) are related to each other, although it is not the purpose of this paper to delve into it. Since we work with a broad domain ("wild animals") would not be correct to say that Zorro or Puma, the two most salience species in this work, are prototypical of all the diversity of the wild animals in the area. Rather, both could be considered prototypical of the domain of carnivores or of the domain of harmful animals.

Within the wild animal's domain, the mammals stand out psychologically, occupying therefore preponderant place in the life of the inhabitants of Cuchilla Nevada in the Sierras Grandes of Córdoba province (Argentina). These findings are consistent with found in the literature (Ulicsni et al. 2013; Soares de Melo et al. 2014; García del Valle et al. 2015). In our work, this group of animals, and in particular the four mammals of greater salience, also occupy a preponderant place in the lists of cultural value (CVS). This linkage is evidenced in the high number of ethnospecies of high CS that have some degree of cultural importance and especially, in the fact that four ethnospecies of greater salience are at the same time, those of greater CVS (i.e. Puma, Vizcacha, Zorro and Liebre). However, these ethnospecies stand out by antagonistic characteristic; Puma and Zorro, the most harmful ethnospecies and Vizcacha and Liebre, beneficial ethnospecies appreciated for their meat. The meaning of this results increases in complexity if we considered that the same animal can represent individual contrasting valuations as the case of 
Vizcacha. It's can valued for their meat but also considered harmful for the agriculture due their digger's habits for construct communal burrows nest.

The concept of cultural value proposed in this work, based on the incorporation of multiple values, contemplates and highlights the important role of harmful ethnospecies in cultural valuations (see example of Gray Heron in Gosler 2017: 651). In previous works, the role of harmful animals in the lives of rural inhabitants of Argentina (Lucherini and Merino 2008; Villar 2015; Tamburini 2016) and Latin America can be appreciated (Silva-Rodríguez et al. 2009; Barbosa et al. 2011; Marchini 2014; Garcia del Valle et al. 2015). For people with animal breeders tradition the loss of breeding animals represent not only material losses, therefore, is probable that emotions occupy an important place in the perception of these conflicts as was pointed out by Nolan and Robin (2001). However, the role of these ethnospecies until now was masked in the quantitative formulations of cultural value widely disseminated in ethnobiological studies where the material and/or utilitarian importance of the species had been privileged (Galeano 2000; Reyes García et al. 2005, Castaneda and Stepp 2007, González Insuasti et al. 2008). The fact that these conflicting's animals outstand in the cognitive salience and cultural importance index, tells us about the preponderant place occupied the human-wildlife conflicts in the cognition of the inhabitants of Cuchilla Nevada and other regions of Argentine and South America (Lucherini and Merino 2008; Marchini 2014).

In our study, the easiest ethnospecies to observe (EO) are not the best known (i.e. LEK) and do not completely explain the place that each animal occupies in the cognition of the collaborators. Instead the
CVS explains the knowledge that people have of them. In that sense, we can affirm that the animals of greater salience are better known in terms of trophic interactions. However, the absence of correlation between LEK and EO could be more robust using other knowledge measures, different from the number of trophic interactions (NTI) that we use. For example, knowledge about the Condor and other scavengers' birds (Comeperro and Carancho), highly visible and emblematic animals for the region, was possibly underestimated due to the generality of the references to the consumption of "carrion" without identifying the dead animals consumed. Also, although the absence of correlation between EO and cognitive salience contradicts the assumptions of Bentley and Rodriguez (2001), it is noted that one of the variables that integrate EO, the perceived abundance (PA), presents a significant relationship with Cognitive salience. This it indicates that there are terms in the mathematical formula of Ease of observation's index that explain better the cognitive salience that others.

The proposed Ease of Observation (EO) concept takes into account the extent to which a given species stands out (perceptual salience) and how common it is (prevalence or commonness) (Zamudio and Hilgert 2018). This is a close concept at the ecological salience commonly used in the literature (Hunn 1999). Similarly, to our work, Zamudio and Hilgert (2018) and Gosler (2017) found trends indicate that the abundance (abundance and distribution in Gosler 2017) is a variable of weight on mental constructs that generate the link with wildlife. However, the outstanding position of the puma in our work would not be due solely to its ecological abundance but also to the conflict generated by its presence. This supports the idea that cognitive salience is a 
parameter that captures multiple assessments of local inhabitants (Zamudio and Hilgert, 2018). According to Gosler (2017) the overall salience of a bird species was strongly influenced by its ecological salience, and this in turn influences the cultural salience. But after time the cultural salience might have a strong influence on the overall salience more or less independently of its ecological salience (Gosler 2017).This highlights the discussion on the mutual influences and causal feedback loops between cognitive and ecological factors previously documented (Gosler 2017; Ludwig 2018a; Zamudio and Hilgert 2018).

Contrary to the reported by Gosler (2017) where the ecological salience was identified as the strongest influence of the overall salience, we think that our results are reflecting an increasing pattern in the region, the conflict between rural people and wildlife (Marchini and Crawshaw, 2015; Quiroga et al. 2016). This in turn, is reflected in the high cultural value of the problematic's species previously indicated. The reduction of habitats as a result of the expansion of agricultural borders (Cabido et al. 2005) and the introduction of exotic species such as Jabalí (Tamburini 2016) are factors that are increasing this conflict at regional and global scales (see Barrios Garcia and Ballari 2012). Even, government regulations on the conservation of species and ecosystems such as the hunting prohibition are counterproductive mechanisms to minimize the problem. In Brazil for example, the high population growth of capybara associated with the prohibition of its hunting produced an increase of road accidents and the spotted fever caused by capybaras resulting in human injury and death (Moreira et al. 2012)

Finally, as a emergent complementary findings of this work we want to note the importance of our results in the analysis of "mental models" of social groups proposed more than a decade ago by Atran et al. (2002), and called recently to be reconsidered (Rival 2018). In his work Atran and collaborators found a preponderance of antagonistic interactions in the discourse of Ladino villagers (non-indigenous), unlike the Itza indigenous who privileged mutualistic interactions between plants and animals. Similar to the Ladinos our finding highlights the model of thinking and acting in the nature of western-based societies such as that studied in the mountains of central Argentina. In that, the antagonistic interactions and conflicts with fauna are accentuated, and they emerge as a pattern of human cognition.

\section{CONCLUSIONS}

The cognitive approach has the potential of extract hidden thought about nature. Understanding local cognitions and perceptions about wildlife may provide a framework to understand how they act in them. Public agents and decision makers must support their decisions based on the local perceptions. The close relationship that these people have with the surrounding ecosystems is a factor that makes them equally responsible for decisions about environment destination. Many times, if people who lived for a long time in one place are left aside, ecosystems will be (re)unbalanced and socio-ecological unpredicted conflicts could occur.

\section{ACKNOWLEDGMENTS}

We want to thank from heart to all the people of Cuchilla Nevada for his predisposition and confidence. Thanks, to 
Violeta Furlan, Valentina Saur, Julieta Torrico and Grabriel Orso for the critical reading of the manuscript and the valuable comments, and to Ricardo Torres for the information provided on the ecology and distribution of wild animals of the province of Córdoba. We would also like to thank the Universidad Nacional de Córdoba, and National Council for Scientific and Technological Research (CONICET).

\section{REFERENCES}

Atran S, Medin D, Ross N, Lynch E, Vapnarsky V, Ek E, Coley J, Timura C, Haenn N (2002) Folkecology, Cultural Epidemiology, and the Spirit of the Commons: A Garden Experiment in the Maya Lowlands, 1991-2001. Current anthropology 43(3):421-450

Balée W, Nolan J (2015) Free listing as a Tool for Assessing Cognitive Realities of Landscape Transformation: A Case Study from Amazonia. In: Isendahl C, Stump D (eds) The Oxford Handbook of Historical Ecology and Applied Archaeology. Online publication, Oxford University Press, Oxford, pp. 1-21

Barbosa JAA, Nobrega VA, Alves RRDN (2011) Hunting practices in the semiarid region of Brazil. Indian Journal of traditional Knowledge10(3): 486-490

Barrios Garcia MN, Ballari SA (2012) Impact of wild boar (Suss crofa) in its introduced and native range: a review. Biological Invasions doi:10.1007/s10530-012-0229-6

Bentley J, Rodriguez G (2001) Honduran folk Entomology. Current Anthropology 42(2):285300

Benz B, Santana FM, Pineda R, Cevallos J, Robles L, De Niz D (1994) Characterization of mestizo plant use in the Sierra de Manantlan, Jalisco-Colima, Mexico. Journal of Ethnobiology 14:23-42

Berlin B (1992) Ethnobiological Classification: principles of categorization of plants and animals in traditional societies. 1 ed. Princeton University Press, New Jersey, USA

Berlin B, Kay P (1991) Basic Color Terms: Their Universality and Evolution.1 ed. University of California Press, Berkley, USA
Bernard HR (2006) Research methods in anthropology: qualitative and quantitative approaches. 4 ed. Alta Mira Press, Oxford, UK

Cabido MR (1985) Las comunidades vegetales de la Pampa de Achala. Sierras de Córdoba, Argentina. Documents Phytosociologiques 9:431-447.

Cabido MR, Funes G, Pucheta E, Vendramini F, Díaz S (1998) A chorological analysis of the mountains form Central Argentina. Is all what we call Sierra Chaco really Chaco? Contribution to the study of the flora and vegetation of the Chaco. Candollea 53(2): 321331

Cabido M, Zak MR, Cingolani A, Cáceres D, Díaz $S$ (2005) Cambios en la cobertura de la vegetación del centro de Argentina ¿Factores directos o causas subyacentes?. En: La heterogeneidad de la vegetación de los agroecosistemas. Facultad de Agronomía Universidad de Buenos Aires (ed), Buenos Aires, pp271-300

Cabrera A (1976). Regiones fitogeográficas argentinas. En: Enciclopedia Argentina de Agricultura y Jardinería.2 ed, Editorial ACME, Argentina

Cáceres D (2001) Diagnóstico Socio productivo de Explotaciones de Pequeños Productores Asentados en la Reserva Hídrica Provincial Pampa de Achala. Córdoba. Administración de Parques Nacionales.

Cáceres D (2004) Caracterización socio productiva de los pobladores de la zona Norte de la reserva hídrica provincial de achala. Administración de Parques Nacionales. Buenos Aires, Argentina

Canevari M, Vaccaro O (2007) Guía de mamíferos del Sur de América del Sur. Ed. LOLA, Buenos Aires

Castaneda H, Stepp JR (2007) Ethnoecological importance value (EIV) methodology: assessing the cultural importance of ecosystems as sources of useful plants for the Guaymi people of Costa Rica. Ethnobotany Research and Applications 5:249-257

Cingolani AM, Renison D, Tecco PA, Gurvich DE, Cabido M (2008) Predicting cover types in a mountain range with long evolutionary grazing history: a GIS approach. Journal of Biogeography 35(3):538-551 
Descola P (2016) La composición de los mundos: Conversaciones con Pierre Carbonnier. $1^{a}$ ed. Capital intelectual, Ciudad Autonoma de Buenos aires, Argentina

Di Rienzo JA, Casanoves F, Balzarini MG, Gonzalez L, Tablada M, Robledo C W (2008) InfoStat, versión 2008, Grupo InfoStat, FCA. Universidad Nacional de Córdoba, Argentina

Ferriz RA, Baigún CR, Dominino J (2010) Distribution patterns and trophic characteristics of salmonids and native species inhabiting high altitude rivers of Pampa de Achala region, Argentina. Neotropical Ichthyology 8(4):851-860

Galeano G (2000) Forest use at the Pacific Coast of Chocó, Colombia: a quantitative approach. Economic Botany 54:358-376.

García del Valle Y, Naranjo EJ, Caballero J, Martorell C, Ruan-Soto F, Enríquez PL (2015) Cultural significance of wild mammals in mayan and mestizo communities of the Lacandon Rainforest, Chiapas, Mexico. Journal of Ethnobiology and Ethnomedicine11:36

González Insuasti MS, Martorell C, Caballero J (2008) Factors that influence the intensity of non-agricultural management of plant resources. Agroforestry Systems 74(1):1-15.

Gosler AG (2017) The Human Factor: Ecological Salience in Ornithology and Ethno-Ornithology. Journal of Ethnobiology 37(4):637-662.

Guber R (2012) La etnografía: método, campo y reflexividad. 1ed Siglo Veintiuno, Buenos Aires, Argentina

Hunn ES (1999) Size as Limiting the Recognition of Biodiversity in Folkbiological Classifications: One of Four Factors Governing the Cultural Recognition of Biological Taxa. In: Medin DL, Atran S (eds) Folkbiology. Harvard University Press, Cambridge, MA, pp. 47-69

Kujawska M, Zamudio F, Hilgert NI (2012) Honey-based mixtures used in home medicine by non-indigenous population of Misiones, Argentina. Evidencebased Complementary and Alternative Medicine doi: 10.1155/2012/579350

Lucherini M, Merino MJ (2008) Perceptions of human-carnivore conflicts in the high Andes of Argentina. Mountain research and development 28(1):81-85
Ludwig D (2018a) Does Cogniton Still Mater in Ethnobiology?. Ethnobiology Letters 9(2):269275

Ludwig D (2018b) Revamping the Metaphysics of Ethnobiological Classification. Current Anthropology 59(4):415-438

Ludwig D (2016) Overlapping ontologies and Indigenous knowledge. From integration to ontological self-determination. Studies in History and Philosophy of Science Part A 59:3645

Marchini S (2014) Dimensiones humanas de los conflictos con fauna silvestre: el caso de Brasil. Boletín Alúna 5(1):48-52

Marchini S, Crawshaw PGJr (2015) Human-Wildlife Conflicts in Brazil: A FastGrowing Issue. Human Dimensions of Wildlife 20(4): 323-328

Martín Crespo MC, Salamanca AB (2007) EI muestreo en la investigación cualitativa. Nure Investigación 27 1-4

Martin GJ (1995) Etnobotánica. Manual de métodos. Fondo mundial para la naturaleza. Ed.UNESCO, Royal Botanic Garden, Londres, UK

Medrano C (2014) Zoo-Sociocosmología qom: Seres humanos, animales y sus relaciones en el gran Chaco. Journal de la Société des Américanistes 100(1):225-257

Monroy R, Flores AG (2015) La fauna silvestre con valor de uso en los huertos frutícolas tradicionales de la comunidad indígena de Xoxocotla, Morelos, México. Etnobiología11(1):44-52

Moreira JR, Ferraz KMP, Herrera EA, Macdonald DW (2012) Capybara: biology, use and conservation of an exceptional neotropical species. ed Springer Science \& Business Media, New York, USA

Narosky T, Yzurieta D (2010) Guía de identificación de aves de Argentina y Uruguay. Mazzini Editores, Buenos Aires

Nolan JM, Katlin EJ, Mcdougal KW, McfarlinMJ, Ward MK (2006) The lovable, the loathsome, and the liminal: emotionality in ethnozoological cognition. Journal of Ethnobiology 26(1):126-138

Nolan JM, Robbins MCE (2001) Emotional meaning and the cognitive organization of ethnozoological domains. Journal of Linguist Anthropology11(2):240-249 
Pieroni A (2001) Evaluation of the cultural significance of wild food botanicals consumed in north-western Tuscany, Italy. Journal of Ethnobiology 21:89-104

Punta Al, Díaz D, García A, González W, llanes C, Losada Weht R, Ludueña M, Martinez O, Oviedo Negro A, Tello G (2014) Voces de Achala. Recuperando historias. 1 ed Centro Cultural Graciela Carena, Córdoba, Argentina

Quinlan M (2005). Considerations for collecting freelists in the field: examples from ethobotany. Field methods 17(3):219-234

Quinlan MB, Quinlan RJ (2007) Modernization and medicinal plant knowledge in a Caribbean horticultural village. Medical AnthropologyQuarterly 21(2):169-192

Quiroga VA, Noss AJ, Paviolo A, Boaglio GI, Di Bitetti MS (2016) Puma density, habitat use and conflict with humans in the Argentine Chaco. Journal for Nature Conservation 31:9-15

Renison D, Cingolani AM, Schinner D (2002) Optimizing restoration of Polylepis australis woodlands: when, where and how to transplant seedlings to the mountains. Ecotropica 8:219-224

Reyes García V, Huanca T, Vadez V, Leonard WR, Wilkie D (2006) Cultural, practical and economic value of wild plants: a quantitative study in the bolivian amazon. Economic Botany 60:62-74

Reyes García V, Vadez V, Huanca T, Leonard W, Wilkie D (2005) Knowledge and consumption of wild plants: a comparative study in two Tsimane' villages in the Bolivian Amazon. Ethnobotany Research y Applications 3:201-208

Rival L (2018) Comment on Ludwig "Revamping the Metaphysics of Ethnobiological Classification". Current Anthropology 59:415-438

Rival L (2016) Botanical ontologies special section of the Journal of Ethnobiology PostFace. Journal of Ethnobiology 36(1):147-149

Rosch E, Mervis CB (1975) Family Resemblances: Studies in the Internal Structure of Categories. Cognitive Psychology 7(4): 573-605

Rosch E, Mervis CB, Gray WD, Johnson DM, Boyes-Braem $P$ (1976) Basic objects in natural categories. Cognitive psychology 8(3):382-439
Ryan S (2004) Pobreza y desarrollo rural: la implementación del Programa Social Agropecuario en la región de Pampa de Achala. Dissertation, I Jornadas de Estudios Agrarios y Agroindustriales de la Región NOA, Salta, Argentina

Silva-Rodríguez EA, Soto-Gamboa M, OrtegaSolís GR, Jiménez JE (2009) Foxes, people and hens: human dimensions of a conflict in a rural area of southern Chile. Revista chilena de historia natural 82(3):375-386

Soares de Melo RS, Da Silva OC, Souto A, Alves, RRN, Schiel N (2014) The role of mammals in local communities living in conservation areas in the Northeast of Brazil: an ethnozoological approach. Tropical Conservation Science 7(3):423-439

SOLAE Ethics Committee, Medinaceli A, Cano EJ, Argueta A, Sanabria OL (2018) Latin American Society of Ethnobiology's Code of Ethics. Ethnobiology Letters 9(1):86-89

Sutrop U (2001) List task and a cognitive salience index. Field Methods13: 263-276

Tamburini DM (2016) La fauna silvestre en las estrategias de reproducción social de los campesinos del Chaco Seco de la Provincia de Córdoba (Argentina). Phd thesis, Universidad Nacional de Córdoba, Argentina

Torres R, Tamburini D (2018) Mamíferos de Córdoba y su estado de Conservación. $1^{\circ}$ Edición. Editorial de la UNC. Córdoba. Argentina

Ulicsni V, Svanberg I, Molnár Z (2013) Folk knowledge of non-domestic mammals among ethnic Hungarians in North-Western Romania. North-Western Journal of Zoology 9(2):383-398

Villar P (2015) El lugar del Puma. Representaciones sociales y cultura material en el valle del cajón (Catamarca, Argentina). KULA. Antropólogos del Atlántico sur 12:30-40

Weller SC, Romney, AK (1988) Systematic data collection. 10 ed. Sage publications, California, USA

Zamudio F, Kujawska M, Hilgert NI. (2010) Honey as Medicinal and Food Resource. comparison between Polish and Multiethnic Settlements of the Atlantic Forest, Misiones, Argentina. Open Complementary Medicine Journal 2:58-73 
Zamudio F, Hilgert NI (2018) Can psychological, emotional and cultural factors influence the cultural significance and knowledge of stingless bees in northern Misiones, Argentina?. In: Patricia V, Silvia RM, Roubik PD (eds) Pot-Pollen, a legacy of stingless bees. Ed. Springer, New York, USA
Zamudio F, Hilgert NI (2015) Multidimensionality and variability in folk classification of stingless bees (Apidae: Meliponini). Journal of ethnobiology and ethnomedicine 11(1): 41
Received: 05 February 2017

Accepted: 18 April 2017

Published: 31 July 2017 


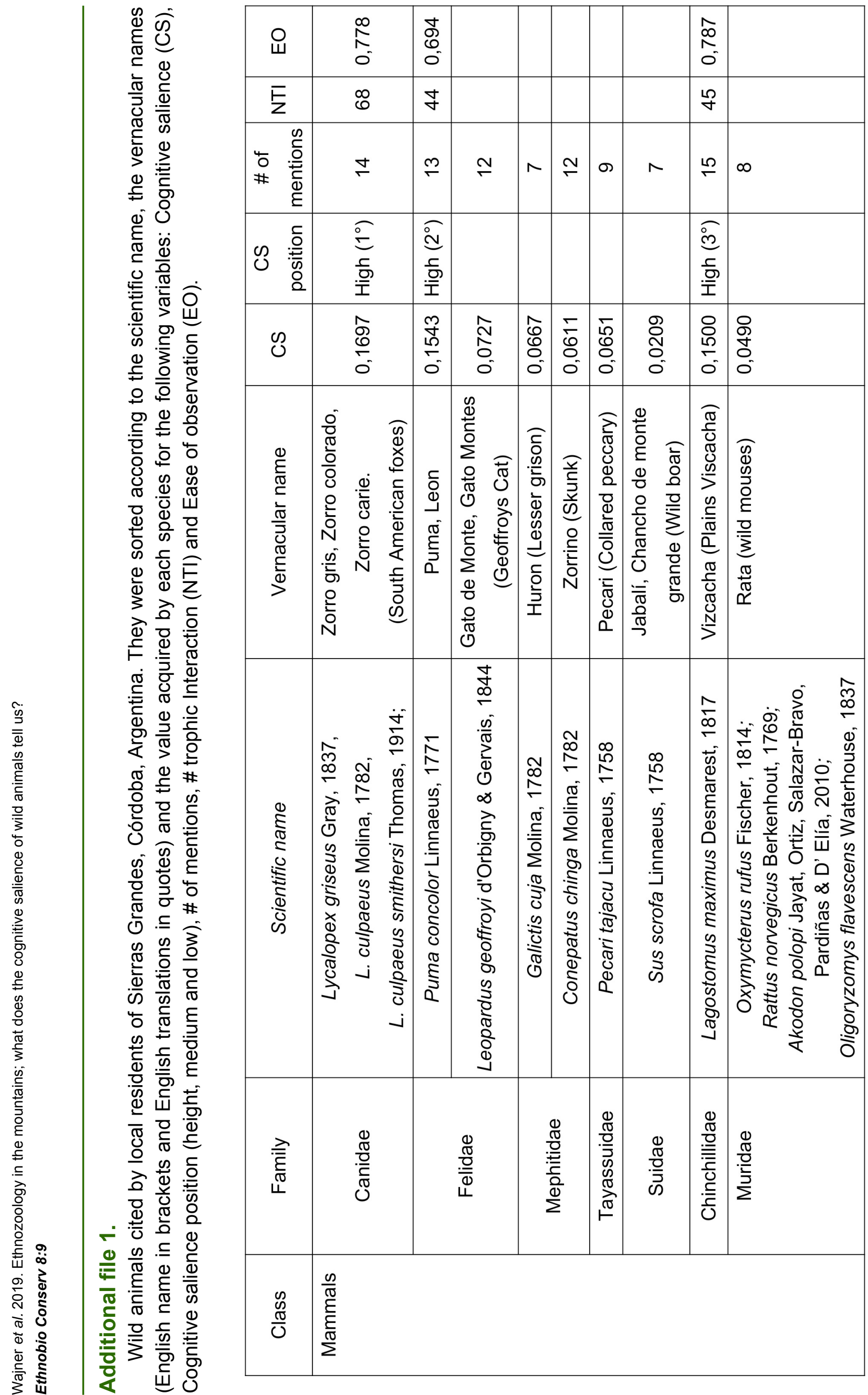




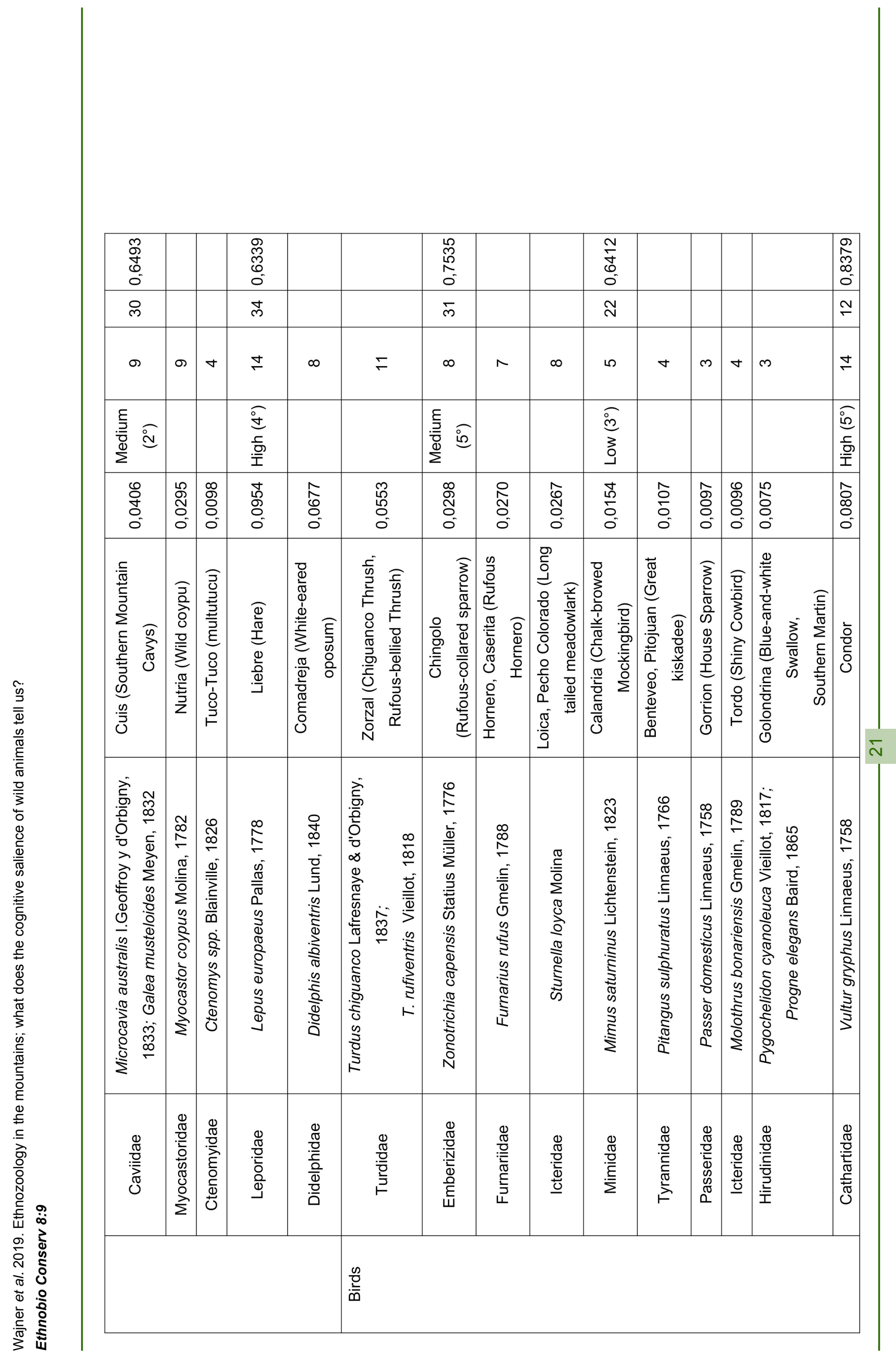




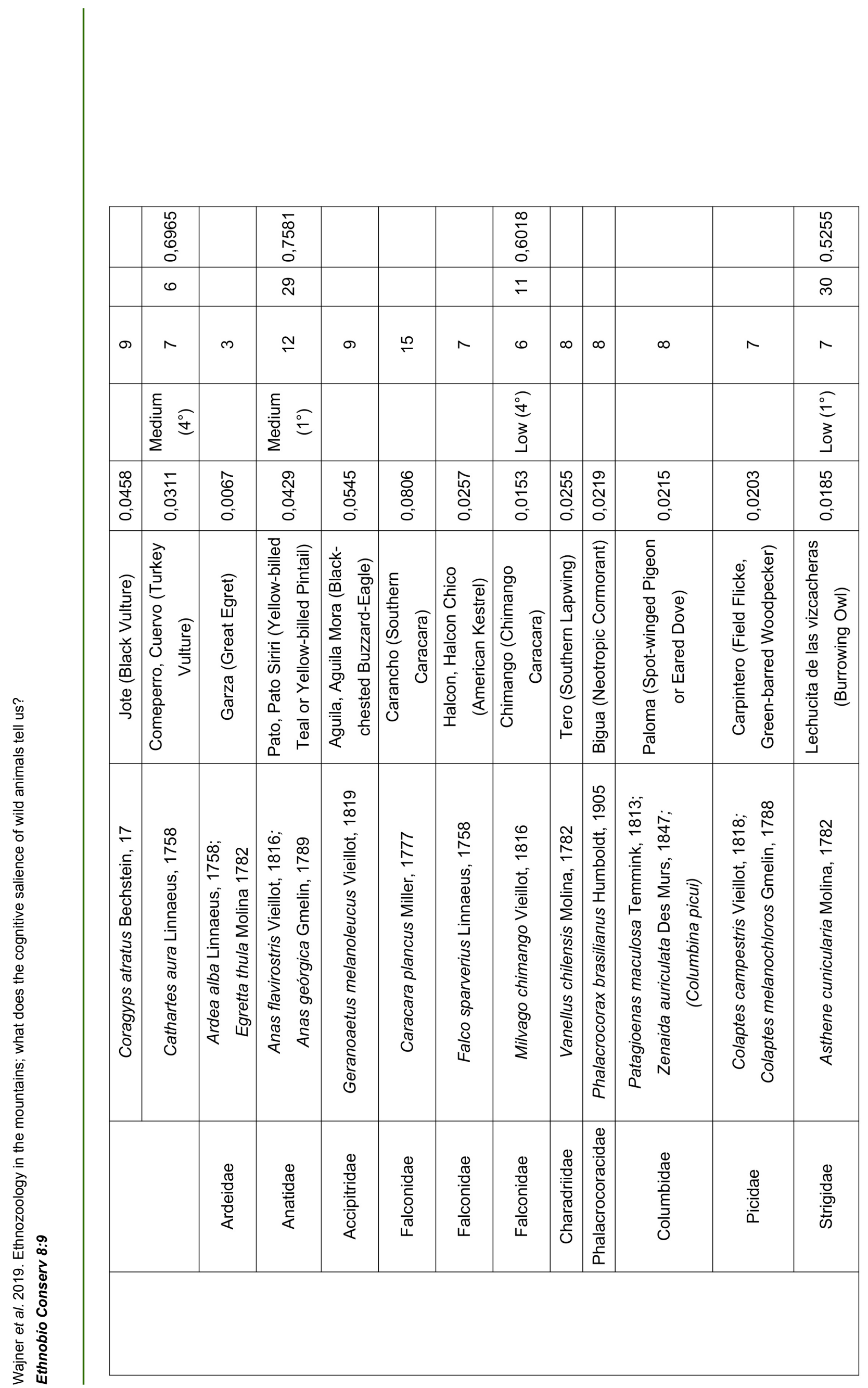




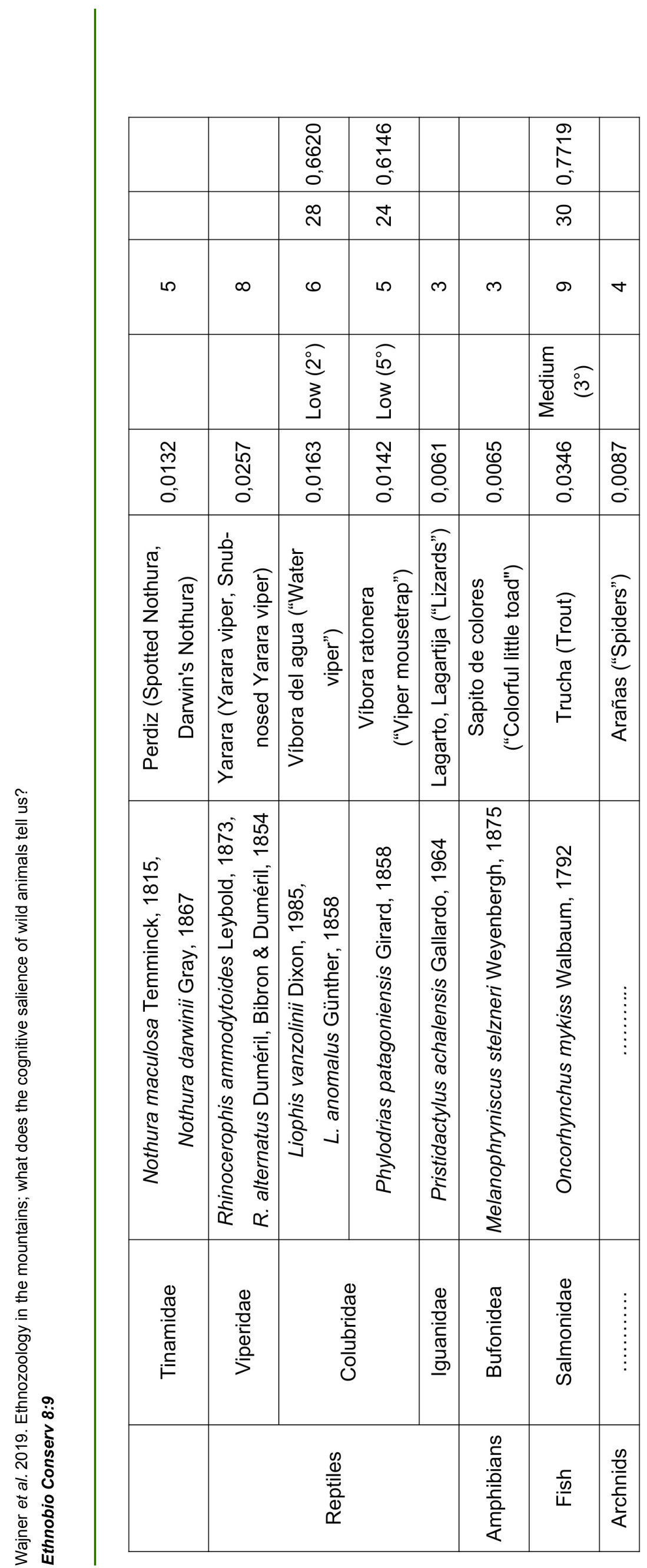

